\title{
The effects of Gamijinhae-tang on elastase/ lipopolysaccharide-induced lung inflammation in an animal model of acute lung injury
}

Sung-Hwa Sohn ${ }^{1,7}$, HaRyeon Jang ${ }^{2}$, Youngeun Kim ${ }^{1}$, Young Pyo Jang ${ }^{3,4}$, Seung-Hun Cho ${ }^{5}$, Heejae Jung ${ }^{2}$, Sungki Jung ${ }^{2^{*}}$ and Hyunsu Bae $e^{1,6^{*}}$

\begin{abstract}
Background: Gamijinhae-tang (GJHT) has long been used in Korea to treat respiratory diseases. The therapeutic effect of GJHT is likely associated with its anti-inflammatory activity. However, the precise mechanisms underlying its effects are unknown. This study was conducted to evaluate the protective effects of GJHT in a porcine pancreatic elastase (PPE) and lipopolysaccharide(LPS) induced animal model of acute lung injury (ALI).

Methods: In this study, mice were intranasally exposed to PPE and LPS for 4 weeks to induce chronic obstructive pulmonary disease (COPD)-like lung inflammation. Two hours prior to PPE and LPS administration, the treatment group was administered GJHT extracts via an oral injection. The numbers of neutrophils, lymphocytes, macrophages and total cells in the bronchoalveolar lavage (BAL) fluid were counted, and pro-inflammatory cytokines were also measured. For histologic analysis, hematoxylin and eosin (H\&E) stains and periodic acid-Schiff (PAS) stains were evaluated.
\end{abstract}

Results: After inducing ALI by treating mice with PPE and LPS for 4 weeks, the numbers of neutrophils, lymphocytes and total cells were significantly lower in the GJHT group than in the ALI group. In addition, the IL-1 $\beta$ and IL-6 levels were significantly decreased in the GJHT group. The histological results also demonstrated the attenuation effect of GJHT on PPE- and LPS-induced lung inflammation.

Conclusions: The results of this study indicate that GJHT has significantly reduces PPE- and LPS-induced lung inflammation. The remarkable protective effects of GJHT suggest its therapeutic potential in COPD treatment.

Keywords: ALI, COPD, Gamijinhae-tang, Elastase, IL-6, IL-1 $\beta$, Goblet cell

\section{Background}

Chronic obstructive pulmonary disease (COPD) is a leading and increasing cause of morbidity and mortality. Worldwide, it is projected to rise to rank fifth in disease burden by 2020, and it now ranks as the third leading cause of death in the USA [1,2]. COPD is characterized by lung parenchyma destruction, mucus hypersecretion, emphysema, an abnormal lung inflammatory response

\footnotetext{
* Correspondence: jskes1@gmail.com; hbae@khu.ac.kr

${ }^{2}$ Division of Allergy and Respiratory System, Department of Oriental Internal

Medicine, College of Oriental Medicine, Kyung Hee University, \#1,

Hoegi-dong, Dongdaemun-gu, Seoul 130-701, Republic of Korea

'Department of Physiology, College of Oriental Medicine, Kyung Hee

University, \#1, Hoegi-dong, Dongdaemun-gu, Seoul 130-701,

Republic of Korea

Full list of author information is available at the end of the article
}

to external stimuli, and progressive airflow limitation [3-5]. The pathophysiology of airways in COPD involves neutrophilic airway inflammation, antiprotease imbalances, and oxidative stress [6]. The major cause of COPD is cigarette smoking [1,7-10]. Tobacco contains high levels of LPS, approximately $1 \%$ of which survives combustion and is an active component of cigarette smoke $[11,12]$. LPS is a major proinflammatory component of gram-negative bacteria. In experimental animals, the exposure of mice to inhaled LPS was shown to cause emphysema-like changes that persisted up to 4 weeks [13]. Recently, Sajjan et al. reported that PPE- and LPStreated mice exhibited pathological and physiological changes typical of COPD, showing airway hyperresponsiveness (AHR) and increased airway inflammation

\section{Biomed Central}


[14]. In this study, we selected the PPE/LPS-treated animal model to better understand the therapeutic effects of herbal medicines on COPD.

Gamijinhae-tang (GJHT) has been used to treat respiratory diseases such as emphysema, bronchitis, asthma, and COPD in Korea for centuries. GJHT contains 16 species of medicinal plants $[15,16]$. In Korean traditional medicine, medicinal plants are generally used in mixtures. Medicinal plants have long been used to treat inflammation and other inflammation-related diseases, and the raw materials of these products are often used to develop new drugs [17-20]. However, the preventative effects and underlying mechanisms of GJHT on pulmonary disorders have not yet been evaluated. In this study, we provide evidence that GJHT has potential preventative effects on COPD.

\section{Methods}

Water extraction of Gamijinhae-tang (GJHT)

Sixteen medical herbs were used to prepare GJHT (Table 1). All herbs were purchased from Omniherb (Omniherb Co., Korea). A total of 258 grams of GJHT was boiled in 1.4 liters of distilled water in an Herb Extractor (Dae-Woong Co., Korea) for $2 \mathrm{hr}$, yielding a final $580 \mathrm{ml}$ of GJHT extract. The supernatant was harvested under sterile conditions by centrifugation and was lyophilized through evaporation at $-80^{\circ} \mathrm{C}$. The lyophilized

Table 1 Perscription of Gamijinhae-Tang (GJHT)

\begin{tabular}{|c|c|c|}
\hline Scientific name & $\begin{array}{l}\text { Amount } \\
(\%)\end{array}$ & $\begin{array}{l}\text { Chemical } \\
\text { marker }\end{array}$ \\
\hline $\begin{array}{l}\text { Rehmannia glutinosa Liboschitz var. } \\
\text { purpurea Makino }\end{array}$ & 14 & 5-HMF \\
\hline $\begin{array}{l}\text { Raphanus sativus var. hortensis for. } \\
\text { acanthiformis MAKINO }\end{array}$ & 14 & \\
\hline $\begin{array}{l}\text { Astragalus membranaceus Bunge. var. } \\
\text { membranaceus }\end{array}$ & 9 & \\
\hline Atractylodes macrocephala Koidz. & 9 & \\
\hline Poria cocos Wolff & 5 & \\
\hline Pinellia ternate (Thunb.) Breit. & 5 & \\
\hline Citrus unshiu Markovich & 5 & Hesperidin \\
\hline Angelica gigas NAKAl & 5 & Decursin \\
\hline Liriope platyphylla F. T. Wang \& T. Tang & 5 & \\
\hline Platycodon grandiflorum A. De Candolle & 5 & \\
\hline Anthriscus sylvestris & 5 & \\
\hline Schisandra chinensis (Turcz.) Baill & 5 & \\
\hline Morus alba $\mathrm{L}$. & 5 & \\
\hline Scutellaria baicalensis & 5 & $\begin{array}{l}\text { Baicalin, } \\
\text { Baicalein }\end{array}$ \\
\hline Sinapis semen & 3 & \\
\hline Glycyrrhiza uralensis FISCH & 3 & \\
\hline Total & 100 & \\
\hline
\end{tabular}

GJHT extract was dissolved in an appropriate volume of sterile PBS prior to its administration to mice.

\section{High performance liquid chromatography (HPLC) Analysis} of GJHT

5-Hydroxymethylfuraldehyde (5-HMF) was purchased from Sigma Aldrich (Wisconsin, UA), and baicalin, baicalein, hesperidin and decursin were purchased from Wako Chemicals (Osaka, Japan). HPLC grade acetonitrile was purchased from J. T. Baker (NJ, USA). A hundred miligram of GJHT extract was dissolved in $1 \mathrm{ml}$ of methanol and distilled water (1:20) and extracted through C18 SPE cartridge (Waters) to remove polysaccharides. Residual portions were recovered and dried under nitrogen to yield $16.1 \mathrm{mg}$ of residue. The residue was dissolved in $1 \mathrm{ml}$ of same solvent above. All standards and sample solutions were filtered through a $0.45 \mathrm{~mm}$ syringe filter (Millipore) before the injection into the Ultra Performance Liquid Chromatography (UPLC). Chromatographic analysis was performed using an Acquity $^{\mathrm{TM}}$ UPLC system (Waters, Milford, MA, USA) comprising a Quaternary Solvent Manager, a Sample Manager - TFN and a PDA detector, and the system was operated by the Waters Empower 3 software. The samples were analyzed with a Acquity UPLC ${ }^{\circledast}$ BEH C18 column $(50 \times 2.1 \mathrm{~mm}$ i.d.; $1.7 \mu \mathrm{m})$ whole through the experiment. The PDA data were collected from 200 to $500 \mathrm{~nm}$. The mobile phase consisted of acetonitrile (solvent A) and water (solvent B) in a linear gradient that increased from $1 \%$ to $100 \%$ of solvent A over $20 \mathrm{mi}$ nutes. The flow rate was $0.5 \mathrm{ml} / \mathrm{min}$ and the injection volume was $2 \mu \mathrm{l}$.

\section{Animals}

The protocols presented below are based on animal experiments approved by the Animal Ethics Committee of Kyung Hee University (12-015). Balb/c male mice (6 weeks of age, weighing $20-25 \mathrm{~g}$ ) were purchased from Charles River Korea (Orient Bio, Seungnam, South Korea). All mice were maintained under specific pathogen-free conditions during the experiments, which were performed according to the ethical principles and guidelines established by the Kyung Hee University for the care and use of experimental animals.

\section{Animal treatment and ALI induction}

The mice were randomly divided into five groups $(\mathrm{n}=$ 5-7/group): (1) control group: negative control mice were sensitized and challenged with PBS alone; (2) ALI group: mice were exposed by the intranasal route to 1.2 units of porcine pancreatic elastase (PPE; Elastin products, Owensville, MO, USA) on day 1 and $7 \mu \mathrm{g}$ of LPS (Calbiochem, Germany) on day 4 of the week for 4 consecutive weeks.; (3) dexa group: positive-control mice 
were administered dexamethasone (1 $\mathrm{mg} / \mathrm{kg}$ body wt) via an oral injection $2 \mathrm{hr}$ prior to PPE and LPS stimulation; (4) GJHT $100 \mathrm{mg} / \mathrm{kg}$ group: mice were administered GJHT (100 mg/kg body wt) via an oral injection $2 \mathrm{hr}$ prior to PPE and LPS stimulation; (5) GJHT $300 \mathrm{mg} / \mathrm{kg}$ group: mice were orally administered GJHT (300 mg/kg body wt) $2 \mathrm{hr}$ prior to PPE and LPS stimulation. On day 32, the mice were sacrificed, and various tissues were collected for analyses.

\section{Analysis of lung inflammatory cells}

Phosphate-buffered saline (PBS) was slowly infused into the lungs and then withdrawn via a cannula that had been inserted into the trachea. The numbers of total and differential cells in the bronchoalveolar lavage (BAL) fluid were then determined using a hemacytometer. In addition, differential cell counts were conducted on slides that were prepared by cytocentrifugation and DiffQuick staining. Approximately 500 cells were counted per slide. The BAL fluids were then centrifuged, and the supernatants were stored at $-80^{\circ} \mathrm{C}$ until needed.

\section{Measurements of IL-1 $\beta$ and IL- 6 in BAL fluid}

The levels of IL- $1 \beta$ and IL- 6 in the BAL fluid were determined using a commercial enzyme immunoassay kit (BD Pharmingen, USA) according to the manufacturer's protocols. A 96-well microtiter plate (Costar, NY, USA) was incubated overnight at $4^{\circ} \mathrm{C}$ with anti-mouse IL-1 $\beta$ and IL-6 monoclonal antibodies in coating buffer and washed with PBS containing 0.05\% Tween 20 (Sigma, MO, USA). The IL-1 $\beta$ and IL-6-coated plates were blocked with $5 \% \mathrm{FBS}$ in PBS for $1 \mathrm{hr}$ at $4^{\circ} \mathrm{C}$ and with $1 \%$ BSA in PBS for 1 hour at room temperature, respectively. BAL fluids $(100 \mu \mathrm{l})$ were then added and incubated for $2 \mathrm{hr}$ at room temperature. Secondary peroxidaselabeled biotinylated anti-mouse IL- $1 \beta$ and IL- 6 monoclonal antibodies were then added and incubated for 1 hour. Finally, the plates were treated with the TMB substrate solution (KPL, CA, USA) for $30 \mathrm{~min}$, and the reaction was stopped with the addition of the TMB stop solution (50 $\mu \mathrm{l}$ per well). The optical density was measured at $450 \mathrm{~nm}$ in a microplate reader (SoftMax PRO, version 3.1 software, CA, USA). The detection limit for IL-1 $\beta$ and IL-6 was $15.6 \mathrm{pg} / \mathrm{ml}$.

\section{Preparation of lung tissues and histology and immunohistochemistry}

Lung tissues were fixed in a $4 \%$ paraformaldehyde solution and then embedded in paraffin. For histological examination, 4- $\mu \mathrm{m}$ sections of lung tissue were stained sequentially with hematoxylin and eosin (H\&E) or periodic acid-Schiff (PAS). To immunohistochemically evaluate neutrophil elastase (NE) and proliferating cell nuclear antigen (PCNA), 4-um sections of lung tissue were treated with $0.3 \% \mathrm{H}_{2} \mathrm{O}_{2}$-methanol for $30 \mathrm{~min}$ to block endogenous peroxidases, after which they were incubated at $4^{\circ} \mathrm{C}$ overnight with anti-NE goat polyclonal antibody (1:50 dilution; Santa Cruz Biotechnology, CA, USA) or anti-PCNA rabbit polyclonal antibody (1:50 dilution; Santa Cruz Biotechnology, CA, USA). The slides were then incubated with avidin-biotin peroxidase complex (ABC kit, Vector Laboratories, CA, USA), after which the color was developed with 3,3'-diaminobenzidine tetrachloride (DAB, Vector Laboratories, CA, USA). Following immunohistochemical staining, the slides were counterstained with Herris's hematoxylin for $2 \mathrm{~min}$ and then mounted with Canada balsam (Showa Chemical Co. Ltd., Japan). Sections with maximum cross-section of parenchyma were selected for morphometry using digitized image analysis. Images were digitized and evaluated with Image Pro-Plus 5.1 software (Media Cybernetics, Inc. Silver Spring, MD, USA). Mean alveolar airspace was determined from the sum of the lumen divided by the number of identified alveoli.

\section{RNA preparation}

The RNA was then isolated from the lung tissue using an Rneasy ${ }^{\oplus}$ Mini Kit (Qiagen, CA, USA) according to the manufacturer's instructions, and the RNA was quantified using NanoDrop (ND-1000; NanoDrop Technologies, Inc., Wilmington, DE, USA).

\section{Real-time RT-PCR analysis}

PAS staining verification was performed via Real-time RT-PCR analysis of Muc5AC and Muc5B genes using LightCycler $^{\circ} 480$ SYBR Green I Master mix and Light Cycler 480 real-time PCR machine (Roche Applied Science, Indianapolis, IN, USA). Expression levels of transcripts were evaluated using the comparative CT method (2-deltaCT). Transcript levels of GAPDH were used for sample normalization. Results are log2transformed fold changes of normalized 2-deltaCT. Data were obtained from three independent experiments and are represented as average \pm standard error. The sequences of the mouse primers were as follows: Muc5AC (FW 5' -cgctaacctgccaaaagaag-3'; RW 5' -gctgaactgggg acaacatt-3'), Muc5B (FW 5' -ccgtcctctttcccaacata-3'; RW $5^{\prime}$-ttggttgtcactctgcttgc-3'), and GAPDH (FW 5'-ttca ccaccatggagaaggc-3'; RW 5' -ggcatggactgtggtcatga-3').

\section{Statistical analysis}

Statistical analysis of the data was conducted using Prism 5 software (GraphPad Software Inc., San Diego, CA, USA). All values are presented as the mean \pm S.E.M. Differences between the means of the control and treatment samples were determined by an one-way ANOVA followed by Newman-Keuls post-hoc test. Results with a $\mathrm{p}<0.05$ were considered statistically significant. The 
power calculation was conducted from one-way ANOVA power analysis based on effect size (SPSS, IBM, Armonk, NY, USA). The power (1- $\beta$ ) was 0.96 from one-way ANOVA power analysis ( $\alpha$ error $=0.05$,effect size $\mathrm{f}=0.97$ ). Therefore total sample size $(n=26)$ was enough to allow for statistically significant finding.

\section{Results}

\section{The HPLC profile of GJHT}

The identified compounds of GJHT using UPLC were listed Table 1 . Five representative chemicals were clearly identified in UPLC chromatograph (Figure 1). Identified peaks and corresponding standard compounds were indicated on the UPLC chromatogram (Figure 1).

\section{The effect of GJHT on pulmonary inflammation}

To determine whether GJHT affects immune cells, mice were subjected to a long-term exposure to PPE and LPS (four weeks, Figure 2). At one week after the final LPS treatment, a significant increase in the total number of cells was observed in the ALI group when compared to the dexamethasone-treated ( $1 \mathrm{mg} / \mathrm{kg}$ body wt) and GJHTtreated (100 or $300 \mathrm{mg} / \mathrm{kg}$ body wt) groups (Figure 3$)$. In addition, the influx of macrophages, neutrophils, and lymphocytes was remarkably higher in the ALI group than in the dexamethasone-treated ( $1 \mathrm{mg} / \mathrm{kg}$ body wt) and GJHTtreated (100 or $300 \mathrm{mg} / \mathrm{kg}$ body wt) groups (Figure 3 ).
The effects of GJHT on pro-inflammatory cytokine production in BAL fluid

To evaluate the effects of GJHT on BAL fluid, the secretion of pro-inflammatory cytokines was measured. IL- $1 \beta$ and IL-6 are known to be pro-inflammatory cytokines that contribute to LPS-induced lung inflammation. Treatment with GJHT significantly reduced the levels of IL-1 $\beta$ and IL- 6 when compared to the ALI group (IL-1 $\beta$; $\mathrm{p}=0.0029, \mathrm{~F}=5.67, \mathrm{R}^{2}=0.52$, and IL-6; $\mathrm{p}=0.032, \mathrm{~F}=3.23$, $\mathrm{R}^{2}=0.38$, Figure 4).

The effect of GJHT on histological changes in lung tissue We also evaluated the effects of GJHT on PPE- and LPS-induced lung damage. We stained lung sections with hematoxylin and eosin (H\&E). We found that lung architecture of ALI group was distinct from controls with respect to alveolar airspace. The ALI group showed alveolar destruction, which resulted in enlarged air spaces, indicating an emphysematous change. By contrast, the dexamethasone-treated ( $1 \mathrm{mg} / \mathrm{kg}$ body $\mathrm{wt}$ ) and GJHT-treated (100 or $300 \mathrm{mg} / \mathrm{kg}$ body wt) groups showed less tissue damage $\left(p<0.0001, F=69.73\right.$, and $R^{2}=0.94$, Figure 5).

\section{The effect of GJHT on goblet cell hyperplasia}

To evaluate the effects of GJHT on goblet cell hyperplasia in lung tissue, the number of PAS-positive cells was evaluated. The ALI group showed more PAS-positive goblet

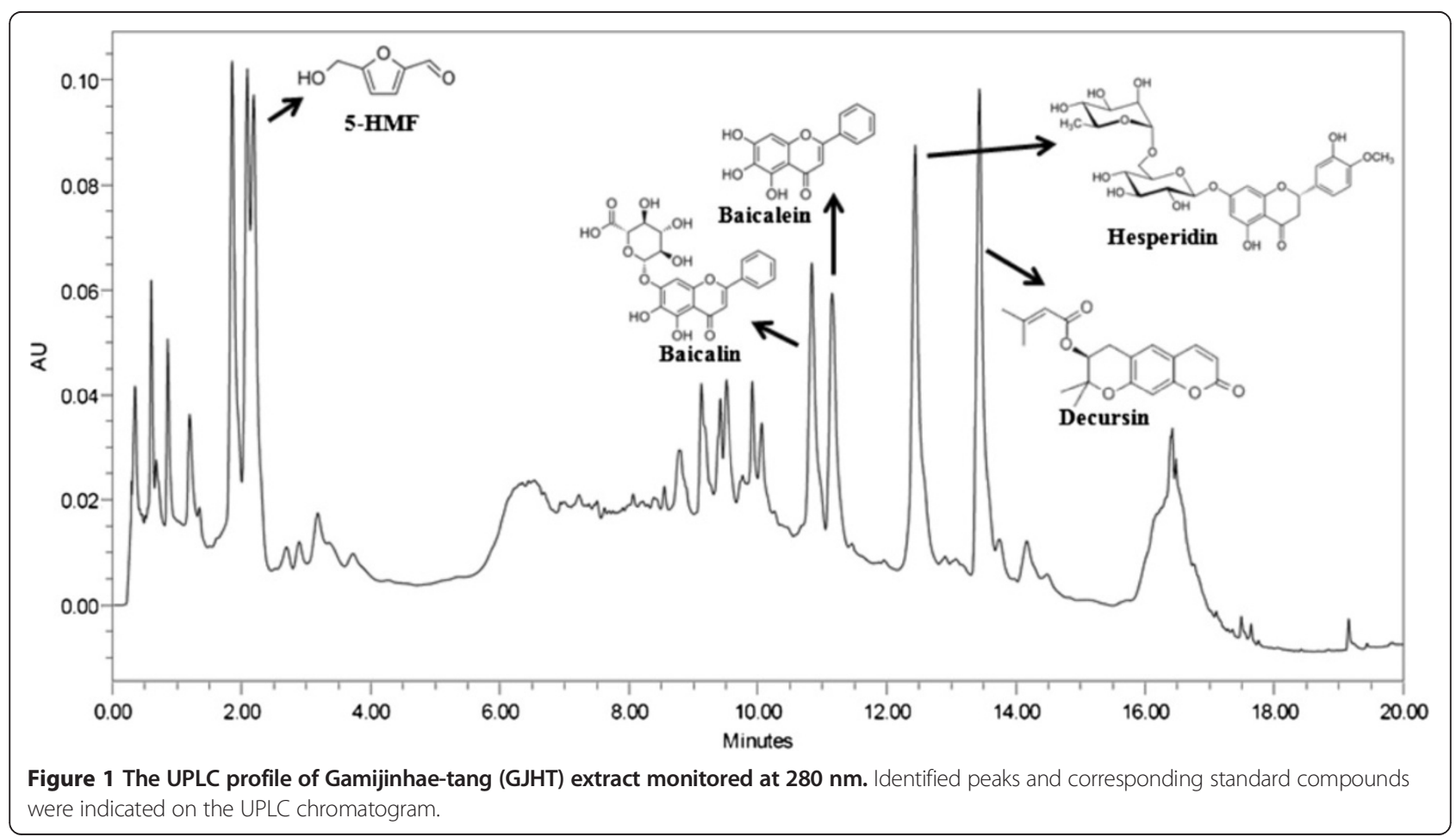




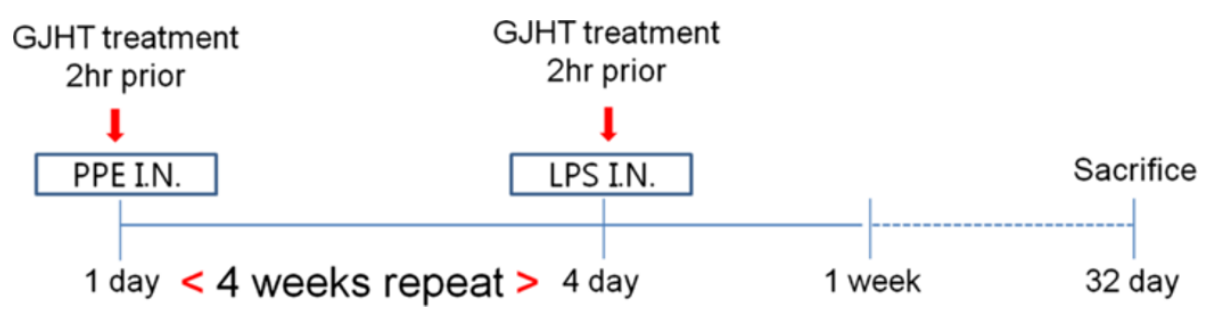

Figure 2 Schematic diagram of the experimental protocol. Animals were exposed by intranasal route to $1.2 \mathrm{U} / \mathrm{kg}$ of porcine pancreatic elastase (PPE) on day 1 and $7 \mathrm{ug} / \mathrm{kg}$ of lipopolysaccaride (LPS) on day 4 of the week for 4 consecutive weeks. The mice were sacrificed on 7 days at after last LPS stimulation.

cells in the large airways. By contrast, dexamethasonetreated (1 $\mathrm{mg} / \mathrm{kg}$ body $\mathrm{wt})$ or GJHT-treated (100 or $300 \mathrm{mg} / \mathrm{kg}$ body wt) groups showed significantly fewer PAS-positive cells than ALI group $(\mathrm{p}<0.0001, \mathrm{~F}=15.94$, and $\mathrm{R}^{2}=0.76$, Figure 5). PAS staining verification was performed via Muc5AC and Muc5B mRNA expression. The mucins Muc5AC and Muc5B are found at increased levels in ALI group. However, dexamethasone-treated (1 mg/kg body wt) or GJHT-treated (100 or $300 \mathrm{mg} / \mathrm{kg}$ body wt) groups are decreased expression than ALI group (Figure 6). These data suggest that treatment with GJHT had a powerful preventative effect on the induced chronic inflammatory lung disease.

\section{Discussion}

Exposures to environmental allergens are the main triggers of asthma, while cigarette smoking is the predominant cause of COPD [21]. Both asthma and COPD are characterized by chronic airway inflammation. The key inflammatory cells involved in COPD $\left(\mathrm{CD}^{+} \mathrm{T}\right.$ cells, macrophages and neutrophils) are different from those involved in asthma (eosinophils and CD4 ${ }^{+}$Th2 cells), suggesting that different treatments may be required $[9,22]$. However, the treatments for both of these diseases may often overlap. The current standard medications for treating inflammatory lung diseases has evolved to cocktail therapies, which are combinations of several

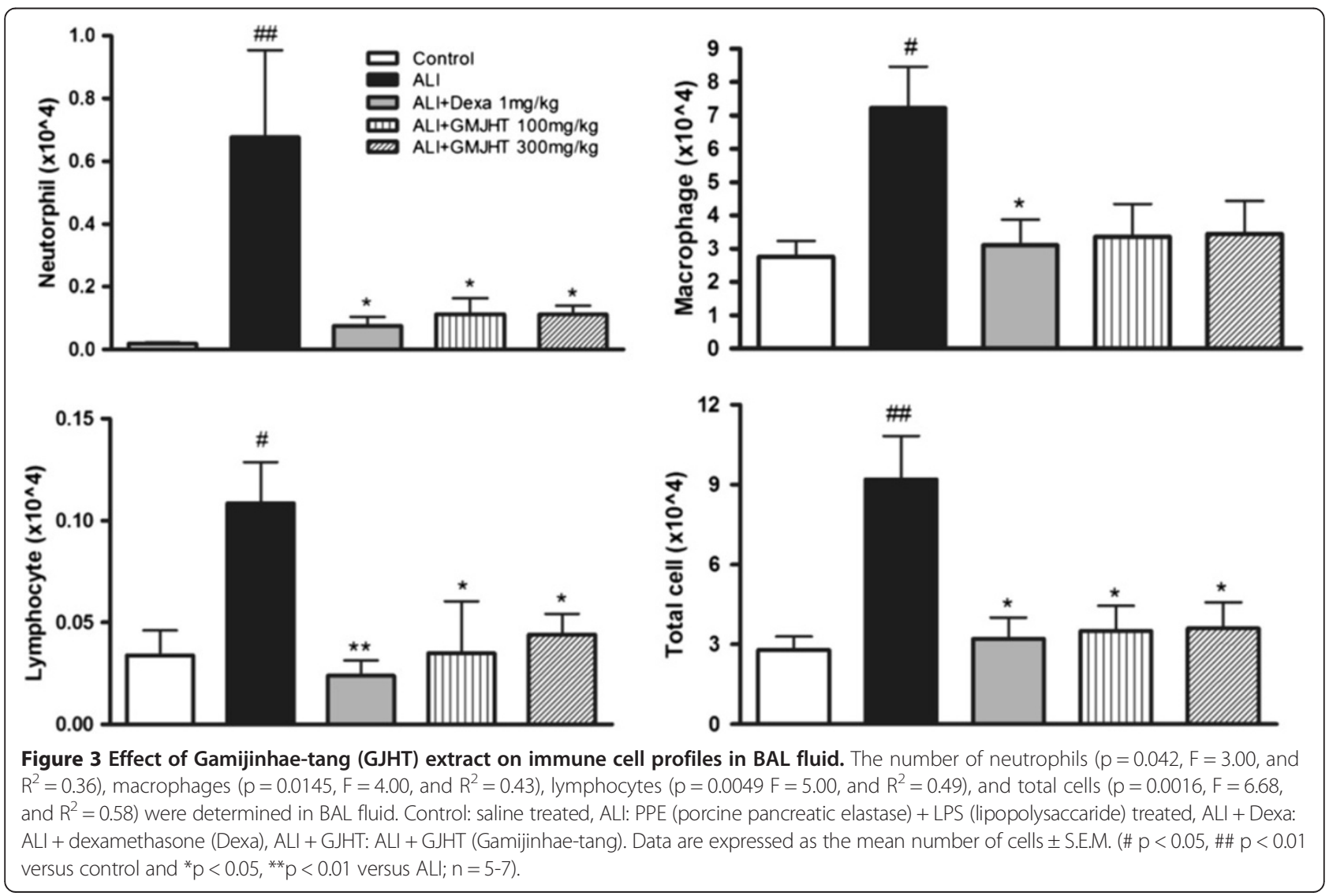




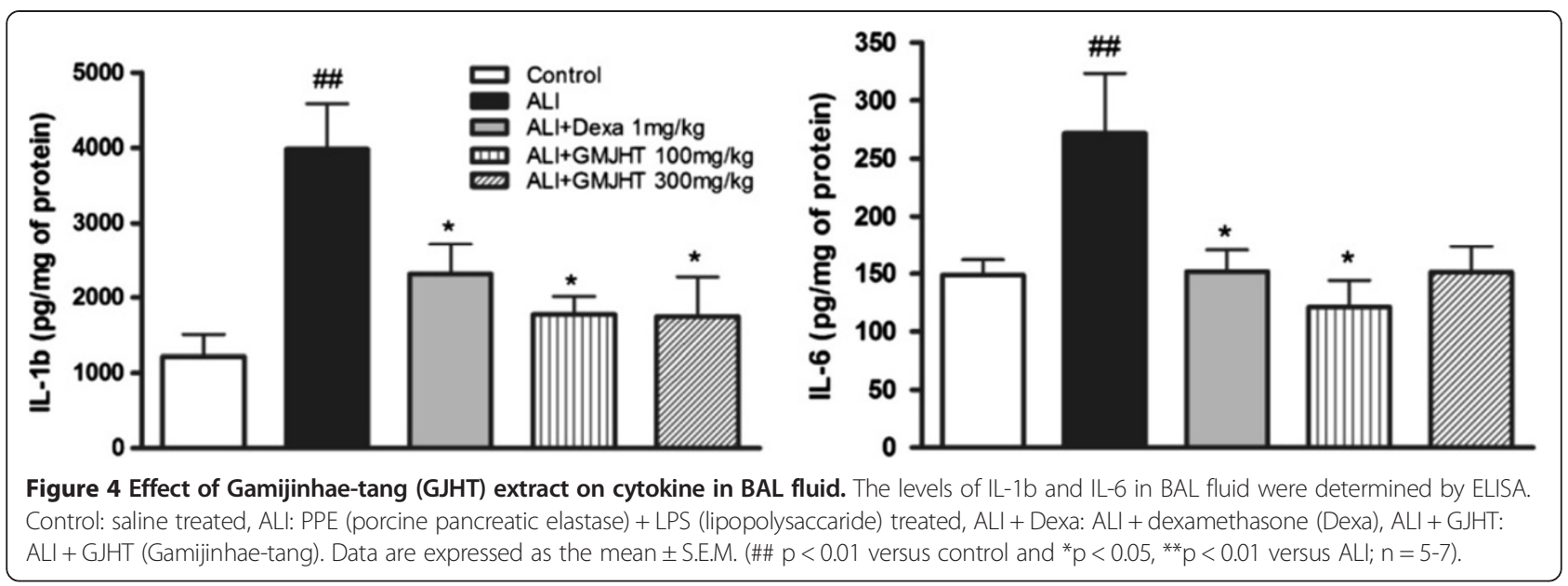

medicines possessing different therapeutic targets and include inhaled glucocorticosteroids, $\beta 2$-adrenoceptor agonists, leukotriene receptor antagonists, methylxanthines, theophylline, and others [23-26]. However, these therapies produce potential side effects, such as growth retardation, the induction of insulin resistance, the loss of bone mass, immune system suppression, cardiac comorbidity, nausea, emesis, gastrointestinal disturbances, and arrhythmias, but they do not consistently ameliorate airway inflammation in some COPD patients [27-33]. Therefore, there is a need for the development of safe and efficacious treatments $[34,35]$. In the present study,

\section{A}
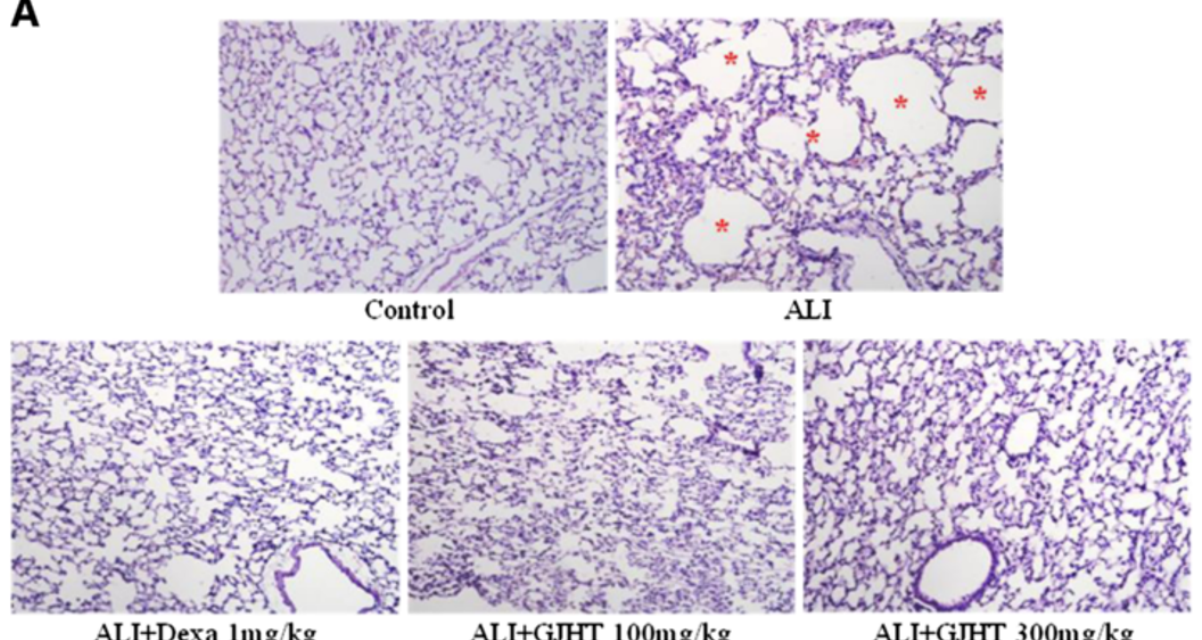

B

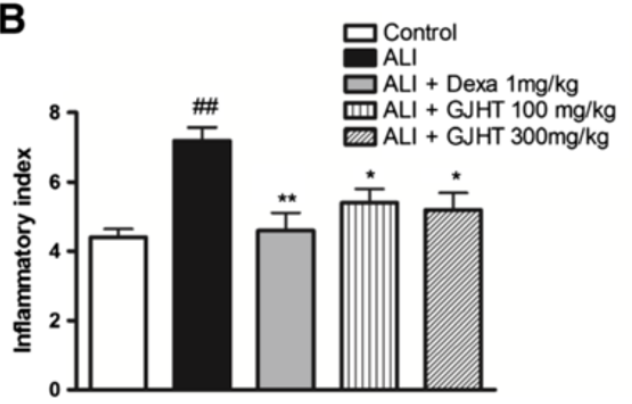

C

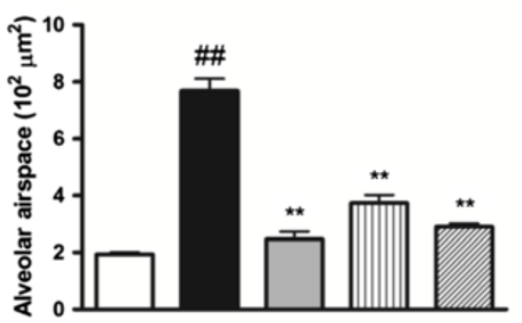

Figure 5 The effect of Gamijinhae-tang (GJHT) extract on lung tissue damage. A) Mouse lung sections were stained with hematoxylin and eosin (magnification $\times 200$ ), B) inflammatory index $\left(p=0.001, F=7.14\right.$, and $\left.R^{2}=0.59\right)$, and $\mathbf{C}$ ) Alveolar airspace. Control: saline treated, ALl: PPE (porcine pancreatic elastase) + LPS (lipopolysaccaride) treated, ALI + Dexa: ALI + dexamethasone (Dexa), ALI + GJHT: ALI + GJHT(Gamijinhae-tang). Data are expressed as the mean \pm S.E.M. (\#\# $\mathrm{p}<0.01$ versus control and ${ }^{*} \mathrm{p}<0.05,{ }^{* *} \mathrm{p}<0.01$ versus ALl; $\mathrm{n}=5-7$ ). 


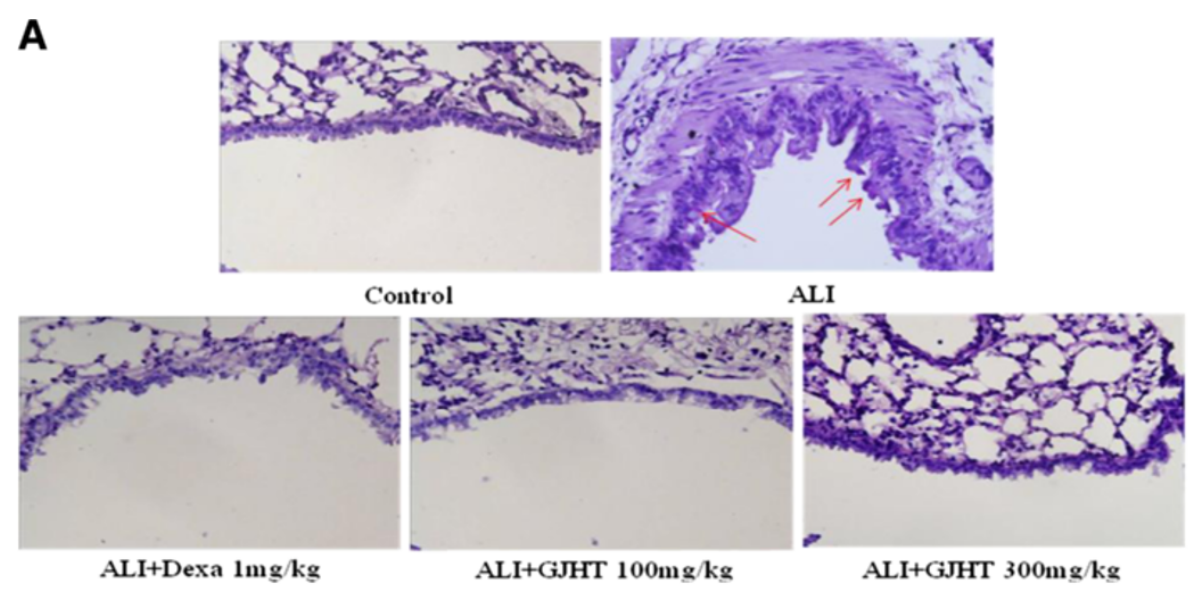

B
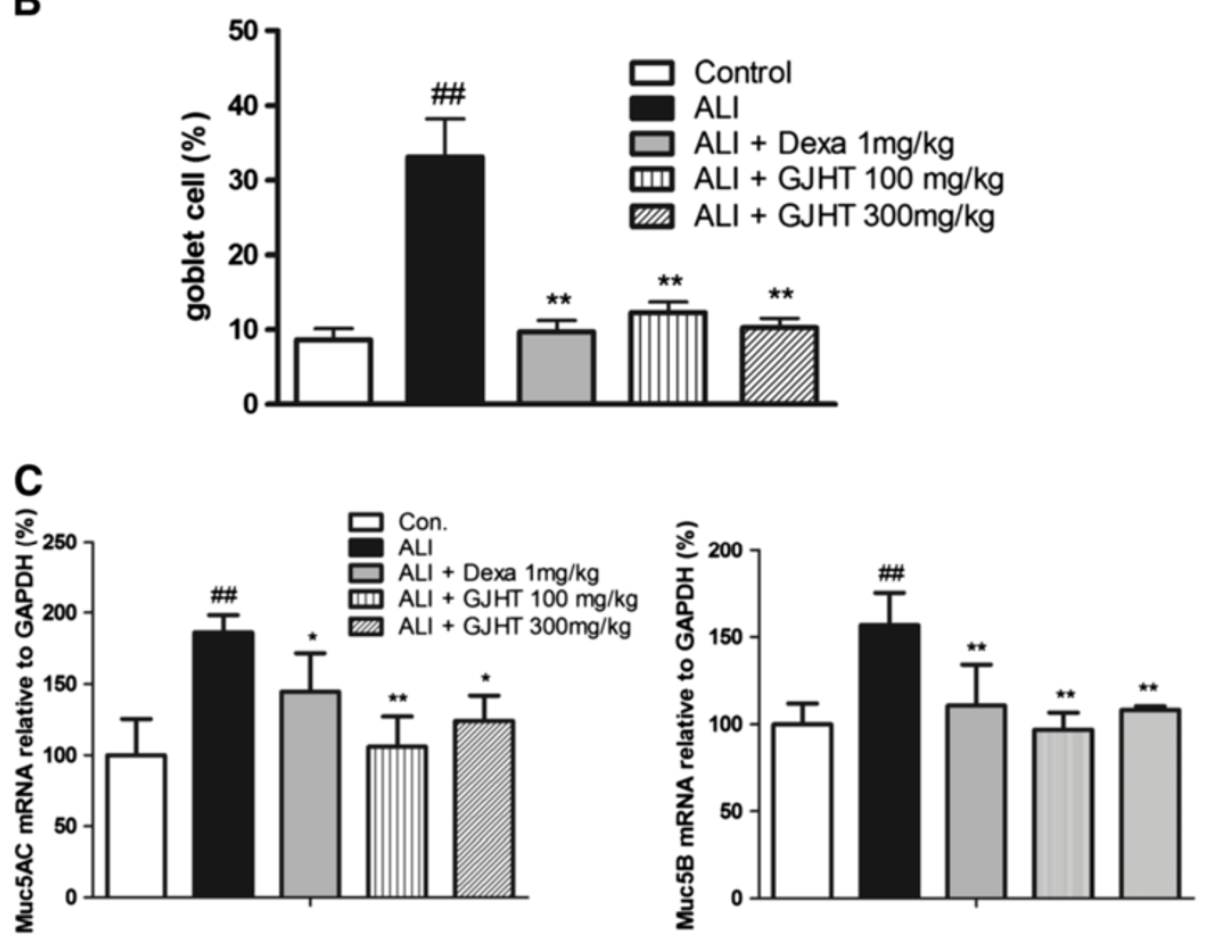

Figure 6 The effect of Gamijinhae-tang (GJHT) extract on goblet cell and musins. A) Mouse lung sections were stained with PAS (magnification $\times 400$ ), B) goblet cell (\%), and C) Muc5AC and Muc5B mRNA expression. Muc5AC and Muc5B mRNA expression were analyzed by quantitative real-time PCR. Expression levels of Muc5AC and Muc5B mRNA were normalized to GAPDH and expressed as the relative quantity to controls. Control: saline treated, ALI: PPE (porcine pancreatic elastase) + LPS (lipopolysaccaride) treated, ALI + Dexa: ALI + dexamethasone (Dexa), $A L I+G J H T: A L I+G J H T$ (Gamijinhae-tang). Data are expressed as the mean \pm S.E.M. (\#\# $p<0.01$ versus control and ${ }^{*} p<0.05$, ${ }^{* *} p<0.01$ versus ALl; $n=5-7)$. The statistic power for Muc5AC; $p=0.0039, F=7.89$, and $R^{2}=0.76$, and for Muc5B; $p=0.0042, F=7.70$, and $R^{2}=0.75$.

we show that exposure to PPE and LPS induces structural and functional changes that are typical of COPD, including airway remodeling, diffuse lung inflammation, goblet cell hyperplasia, alveolar enlargement, and increased numbers of neutrophils, lymphocytes, and macrophages in the airways and alveoli. In addition, in the airways the mucins Muc5AC and Muc5B are found at increased levels in both asthmatic and COPD subjects
[36,37]. Mucin hypersecretion is associated with abnormal epithelial cell growth and differentiation, both inflammatory mediators and growth factors may be involved in the stimulation of mucin production from goblet cells [38]. However, GJHT treatment ameliorated the lung structural and functional changes in the PPE and LPS exposure model. These results may suggest that GJHT is a useful therapeutic agent that prevents 
the structural and functional changes associated with COPD.

The components of GJHT have been shown to have various biological effects. Rehmannia glutinosa, a major component of GJHT, possesses thrombolytic, hyperglycemic, and anti-inflammatory activities and improves renal functions in diabetic nephropathy [39-43]. In addition, this herb has been reported to suppress the production of TNF- $\alpha$ and IL-1 in mouse astrocytes [44]. Atractylodes macrocephala, another component of GJHT, possesses antioxidant, hepatoprotective, antiinflammatory, anti-allergic, antithrombotic, antiviral and anticarcinogenic activities [45-47]. Angelica sinensis is well known to have strong immune regulatory effects, such as antiviral activities and improving immune function by increasing $\mathrm{CD} 4^{+}$cells and the $\mathrm{CD} 4^{+} / \mathrm{CD}^{+}$ratio [48]. Liriope platyphylla has been used to treat asthma and bronchial and lung inflammation [49]. In addition, this compound possesses various therapeutic effects for conditions such as obesity, diabetes, inflammation and neurodegenerative disease [50-53]. Scutellaria baicalensis has been used to treat inflammation, cancer, bacterial and viral infections of the respiratory and gastrointestinal tracts [54-56]. Some of the components of GJHT are reported to possess anti-cancer effects for various types of malignancy via distinct molecular mechanisms and include Raphanus sativus [57,58], Astragalus membranaceus [59-61], Poria cocos [62], Citrus unshiu [63], Platycodon grandiflorum [64] and Anthriscus sylvestris [65]. The therapeutic potency of GJHT should be attributed to its combined and synergistic effects on multiple targets as a result of the diverse components of GJHT. In addition, according to the formula suggested by US Food and Drug Administration [66], human equivalent dose (HED) calculated from mice dosage $(100 \mathrm{mg} / \mathrm{kg}$ and $300 \mathrm{mg} / \mathrm{kg})$ used in this study was $480 \mathrm{mg} / 60 \mathrm{~kg}$ and $1440 \mathrm{mg} / 60 \mathrm{~kg}$ in human, respectively. We believe that these amounts of GJHT would be applicable dosages to human.

The morphological and inflammatory changes were accompanied by increases in lung IL-1 $\beta$ and IL-6, as observed in humans with COPD $[67,68]$. A recent genetic analysis study demonstrated that IL6, ILIRN, IL1B, and IFNG genes were risk factors for the accelerated decline of lung function or baseline lung function in COPD patients [69]. Importantly, their study demonstrated a significant association between IL6 and an IL6-smoking interaction in cardiovascular disease [69]. In addition, high levels of serum or sputum IL-6 have been associated with impaired lung function, pulmonary infections, exacerbations, and skeletal muscle weakness in COPD patients [70-74]. Experimental studies have shown that IL-6 overexpression in the murine lung results in emphysema-like airspace enlargement and airway inflammation [75]. In the present study, GJHT treatment significantly reduced the amounts of IL- $1 \beta$ and IL- 6 in the airway, suggesting that the anti-inflammatory effect of GJHT can be attributed to the suppression of proinflammatory cytokine production in the lung. Even though the power calculation result demonstrated that the animal number used in this study was enough to tell the statistical importance, the sample size of this study was relatively small ( $n=5,6$ each group) that might mislead the data interpretation. To overcome such limitations, additional researches investigating the mechanism of Gamijinhae-tang on lung inflammation are necessary.

\section{Conclusions}

Taken together, the results of this study suggest that GJHT significantly reduces PPE- and LPS-induced lung inflammation. The anti-inflammatory effects of GJHT indicate that it has therapeutic potential for chronic obstructive pulmonary disease.

\section{Competing interests}

The authors declare that they have no competing interests.

\section{Authors' contribution}

SS, HJ and YK have made contribution to acquisition and analyzing data. YPJ, SC and $\mathrm{HJ}$ have made been involved in interpretation of data. SS, SJ and HB have been involved in designing the study and drafting the manuscript. All authors read and gave final approval for the version submitted for publication.

\section{Acknowledgements}

This work was supported by the National Research Foundation of Korea (NRF) grant funded by the Korean government (Ministry of Education, Science and Technology, MEST) (No. 2011-0006220).

\section{Author details}

${ }^{1}$ Department of Physiology, College of Oriental Medicine, Kyung Hee University, \#1, Hoegi-dong, Dongdaemun-gu, Seoul 130-701, Republic of Korea. ${ }^{2}$ Division of Allergy and Respiratory System, Department of Oriental Internal Medicine, College of Oriental Medicine, Kyung Hee University, \#1, Hoegi-dong, Dongdaemun-gu, Seoul 130-701, Republic of Korea. ${ }^{3}$ Division of Pharmacognosy, College of Pharmacy, Kyung Hee University, \#1, Hoegi-dong, Dongdaemun-gu, Seoul 130-701, Republic of Korea. ${ }^{4}$ Department of Life and Nanopharmaceutical Science, College of Pharmacy, Kyung Hee University, \#1, Hoegi-dong, Dongdaemun-gu, Seoul 130-701, Republic of Korea.

${ }^{5}$ Department of Neuropsychiatry, College of Oriental Medicine, Kyung Hee University, \#1, Hoegi-dong, Dongdaemun-gu, Seoul 130-701, Republic of Korea. ${ }^{6}$ Institute of Oriental Medicine, Kyung Hee University, Seoul 130-701, South Korea. ${ }^{7}$ Present Address: National Academy of Agricultural Science, Rural Development Administration, Suwon 441-707, South Korea.

Received: 10 September 2012 Accepted: 15 July 2013

Published: 16 July 2013

\section{References}

1. Rabe KF, Hurd S, Anzueto A, Barnes PJ, Buist SA, Calverley P, Fukuchi Y, Jenkins C, Rodriguez-Roisin R, van Weel C, et al: Global strategy for the diagnosis, management, and prevention of chronic obstructive pulmonary disease: GOLD executive summary. Am J Respir Crit Care Med 2007, 176(6):532-555.

2. Cho MH, Castaldi PJ, Wan ES, Siedlinski M, Hersh CP, Demeo DL, Himes BE, Sylvia JS, Klanderman BJ, Ziniti JP, et al: A genome-wide association study of COPD identifies a susceptibility locus on chromosome 19q13. Hum Mol Genet 2012, 21(4):947-957.

3. Pauwels RA, Buist AS, Ma P, Jenkins CR, Hurd SS: Global strategy for the diagnosis, management, and prevention of chronic obstructive pulmonary disease: National Heart, Lung, and Blood Institute and World 
Health Organization Global Initiative for Chronic Obstructive Lung Disease (GOLD): executive summary. Respir Care 2001, 46(8):798-825.

4. Barnes PJ: Chronic obstructive pulmonary disease. N Engl J Med 2000, 343(4):269-280.

5. Konigshoff $\mathrm{M}$, Kneidinger $\mathrm{N}$, Eickelberg $\mathrm{O}$ : TGF-beta signaling in COPD: deciphering genetic and cellular susceptibilities for future therapeutic regimen. Swiss Med Wkly 2009, 139(39-40):554-563.

6. Groneberg DA, Chung KF: Models of chronic obstructive pulmonary disease. Respir Res 2004, 5:18.

7. Ferrer E, Peinado VI, Diez M, Carrasco JL, Musri MM, Martinez A, RodriguezRoisin R, Barbera JA: Effects of cigarette smoke on endothelial function of pulmonary arteries in the guinea pig. Respir Res 2009, 10:76.

8. Hogg JC, Chu F, Utokaparch S, Woods R, Elliott WM, Buzatu L, Cherniack RM, Rogers RM, Sciurba FC, Coxson HO, et al: The nature of small-airway obstruction in chronic obstructive pulmonary disease. N Engl J Med 2004, 350(26):2645-2653.

9. Barnes PJ: The cytokine network in asthma and chronic obstructive pulmonary disease. J Clin Invest 2008, 118(11):3546-3556.

10. Barnes PJ: Mediators of chronic obstructive pulmonary disease. Pharmacol Rev 2004, 56(4):515-548.

11. Hasday JD, Bascom R, Costa JJ, Fitzgerald T, Dubin W: Bacterial endotoxin is an active component of cigarette smoke. Chest 1999, 115(3):829-835.

12. Sebastian A, Pehrson C, Larsson L: Elevated concentrations of endotoxin in indoor air due to cigarette smoking. J Environ Monit 2006, 8(5):519-522.

13. Brass DM, Hollingsworth JW, Cinque M, Li Z, Potts E, Toloza E, Foster WM, Schwartz DA: Chronic LPS inhalation causes emphysema-like changes in mouse lung that are associated with apoptosis. Am J Respir Cell Mol Biol 2008, 39(5):584-590.

14. Sajjan U, Ganesan S, Comstock AT, Shim J, Wang Q, Nagarkar DR, Zhao Y, Goldsmith AM, Sonstein J, Linn MJ, et al: Elastase- and LPS-exposed mice display altered responses to rhinovirus infection. Am J Physiol Lung Cell Mol Physiol 2009, 297(5):L931-L944.

15. Kim Y, Joo Y, Jung HJ, Seo U: Effects of Gamijinhae-tang (Jiaweizhenketang) on Tracheal Smooth Muscle Contraction and Mucin Secretion from Airway Epithelial Cells. J Korean Oriental Med 2008, 29(3):63-75.

16. Byun J, Park YB, Yang S, An J, Park S: Effects of Gamijinhae-tang and Socheongryong-tang-ga-seokgo on PMA- induced Production of Airway Mucin and Expression of Airway MUC5AC Gene. J Korean Oriental Inten Med 2008, 29(3):765-777.

17. Chung HS, Kang M, Cho C, Parvez S, Park CH, Kim D, Oh J, Kim H, Shin M, Hong $M$, et al: Inhibition of nitric oxide and tumor necrosis factor-alpha by moutan cortex in activated mouse peritoneal macrophages. Biol Pharm Bull 2007, 30(5):912-916.

18. Sohn SH, Ko E, Oh BG, Kim J, Choi E, Kim SH, Kim Y, Shin M, Hong M, Bae H: Global gene analysis of Erigeron canadensis-treated TNF-alpha-, IL-4and IL-1beta-stimulated A549 human epithelial cells. Ann Nutr Metab 2009, 54(3):227-235

19. Sohn $\mathrm{SH}$, Ko E, Kim Y, Shin M, Hong M, Bae H: Genomewide expression profile of forsythia suspensa on lipopolysaccaride-induced activation in microglial cells. Mol Cell Toxicol 2008, 4(2):113-123.

20. Sohn SH, Ko E, Oh BG, Kim SH, Kim Y, Shin M, Hong M, Bae H: Inhibition effects of Vitex rotundifolia on inflammatory gene expression in A549 human epithelial cells. Ann Allergy Asthma Immunol 2009, 103(2):152-159.

21. Tamimi A, Serdarevic D, Hanania NA: The effects of cigarette smoke on airway inflammation in asthma and COPD: therapeutic implications. Respir Med 2012, 106(3):319-328.

22. Barnes PJ: Immunology of asthma and chronic obstructive pulmonary disease. Nat Rev Immunol 2008, 8(3):183-192.

23. Masoli M, Fabian D, Holt $\mathrm{S}$, Beasley R: The global burden of asthma: executive summary of the GINA Dissemination Committee report. Allergy 2004, 59(5):469-478

24. Bousquet J, Clark TJ, Hurd S, Khaltaev N, Lenfant C, O'Byrne P, Sheffer A: GINA guidelines on asthma and beyond. Allergy 2007, 62(2):102-112.

25. Burge PS, Lewis SA: So inhaled steroids slow the rate of decline of FEV1 in patients with COPD after all? Thorax 2003, 58(11):911-913.

26. Calverley PM, Boonsawat W, Cseke Z, Zhong N, Peterson S, Olsson H: Maintenance therapy with budesonide and formoterol in chronic obstructive pulmonary disease. Eur Respir J 2003, 22(6):912-919.

27. Busse WW, Lemanske RF Jr: Asthma. N Engl J Med 2001, 344(5):350-362.

28. Longui CA: Glucocorticoid therapy: minimizing side effects. J Pediatr (Rio J) 2007, 83(5 Suppl):S163-S177.
29. Lemanske RF Jr, Allen DB: Choosing a long-term controller medication in childhood asthma. The proverbial two-edged sword. Am J Respir Crit Care Med 1997, 156(3 Pt 1):685-687.

30. Page CP, Spina D: Phosphodiesterase inhibitors in the treatment of inflammatory diseases. Handb Exp Pharmacol 2011, 204:391-414.

31. Hawkins NM, Wang D, Petrie MC, Pfeffer MA, Swedberg K, Granger CB, Yusuf S, Solomon SD, Ostergren J, Michelson EL, et al: Baseline characteristics and outcomes of patients with heart failure receiving bronchodilators in the CHARM programme. Eur I Heart Fail 2010, 12(6):557-565.

32. Hawkins NM, Jhund PS, Simpson CR, Petrie MC, Macdonald MR, Dunn FG, Macintyre K, McMurray JJ: Primary care burden and treatment of patients with heart failure and chronic obstructive pulmonary disease in Scotland. Eur J Heart Fail 2010, 12(1):17-24.

33. Carpenter DO, Briggs DB, Knox AP, Strominger N: Excitation of area postrema neurons by transmitters, peptides, and cyclic nucleotides. J Neurophysiol 1988, 59(2):358-369.

34. Blanc PD, Trupin L, Earnest G, Katz PP, Yelin EH, Eisner MD: Alternative therapies among adults with a reported diagnosis of asthma or rhinosinusitis : data from a population-based survey. Chest 2001, 120(5):1461-1467.

35. Clark CE, Arnold E, Lasserson TJ, Wu T: Herbal interventions for chronic asthma in adults and children: a systematic review and meta-analysis. Prim Care Respir J 2010, 19(4):307-314.

36. Turner J, Jones CE: Regulation of mucin expression in respiratory diseases. Biochem Soc Trans 2009, 37(Pt 4):877-881.

37. Rogers DF: Airway mucus hypersecretion in asthma: an undervalued pathology? Curr Opin Pharmacol 2004, 4(3):241-250.

38. Rose MC, Voynow JA: Respiratory tract mucin genes and mucin glycoproteins in health and disease. Physiol Rev 2006, 86(1):245-278.

39. Kubo M, Asano T, Shiomoto H, Matsuda H: Studies on rehmanniae radix. I. Effect of $50 \%$ ethanolic extract from steamed and dried rehmanniae radix on hemorheology in arthritic and thrombosic rats. Biol Pharm Bull 1994, 17(9):1282-1286.

40. Kiho T, Watanabe T, Nagai K, Ukai S: Hypoglycemic activity of polysaccharide fraction from rhizome of Rehmannia glutinosa Libosch. $\mathrm{f}$. hueichingensis Hsiao and the effect on carbohydrate metabolism in normal mouse liver. Yakugaku Zasshi 1992, 112(6):393-400.

41. Baek GH, Jang YS, Jeong SI, Cha J, Joo M, Shin SW, Ha KT, Jeong HS: Rehmannia glutinosa suppresses inflammatory responses elicited by advanced glycation End products. Inflamm 2012, 35(4):1232-1241.

42. Kang DG, Sohn EJ, Moon MK, Lee YM, Lee HS: Rehmannia glutinose ameliorates renal function in the ischemia/reperfusion-induced acute renal failure rats. Biol Pharm Bull 2005, 28(9):1662-1667.

43. Yokozawa T, Kim HY, Yamabe N: Amelioration of diabetic nephropathy by dried Rehmanniae Radix (Di Huang) extract. Am J Chin Med 2004, 32(6):829-839

44. Kim HM, An CS, Jung KY, Choo YK, Park JK, Nam SY: Rehmannia glutinosa inhibits tumour necrosis factor-alpha and interleukin-1 secretion from mouse astrocytes. Pharmacol Res 1999, 40(2):171-176.

45. Dong $\mathrm{H}$, He L, Huang $\mathrm{M}$, Dong $\mathrm{Y}$ : Anti-inflammatory components isolated from Atractylodes macrocephala Koidz. Nat Prod Res 2008, 22(16):1418-1427.

46. Li CQ, He LC, Dong HY, Jin JQ: Screening for the anti-inflammatory activity of fractions and compounds from Atractylodes macrocephala koidz. J Ethnopharmacol 2007, 114(2):212-217.

47. Shan JJ, Tian GY: [Studies on physico-chemical properties and hypoglycemic activity of complex polysaccharide AMP-B from Atractylodes macrocephala Koidz]. Yao Xue Xue Bao 2003, 38(6):438-441.

48. Yang T, Jia M, Zhou S, Pan F, Mei Q: Antivirus and immune enhancement activities of sulfated polysaccharide from Angelica sinensis. Int I Biol Macromol 2012, 50(3):768-772.

49. Lee YC, Lee JC, Seo YB, Kook YB: Liriopis tuber inhibit OVA-induced airway inflammation and bronchial hyperresponsiveness in murine model of asthma. J Ethnopharmacol 2005, 101(1-3):144-152.

50. Choi SB, Wha JD, Park S: The insulin sensitizing effect of homoisoflavoneenriched fraction in Liriope platyphylla Wang et Tang via PI3-kinase pathway. Life Sci 2004, 75(22):2653-2664.

51. Jeong S, Chae K, Jung YS, Rho YH, Lee J, Ha J, Yoon KH, Kim GC, Oh KS, Shin SS, et al: The Korean traditional medicine Gyeongshingangjeehwan inhibits obesity through the regulation of leptin and PPARalpha action in OLETF rats. J Ethnopharmacol 2008, 119(2):245-251. 
52. Kim SW, Chang IM, Oh KB: Inhibition of the bacterial surface protein anchoring transpeptidase sortase by medicinal plants. Biosci Biotechnol Biochem 2002, 66(12):2751-2754.

53. Hur J, Lee P, Kim J, Kim AJ, Kim H, Kim SY: Induction of nerve growth factor by butanol fraction of Liriope platyphylla in C6 and primary astrocyte cells. Biol Pharm Bull 2004, 27(8):1257-1260.

54. Li HB, Jiang Y, Chen F: Separation methods used for Scutellaria baicalensis active components. J Chromatogr B Analyt Technol Biomed Life Sci 2004, 812(1-2):277-290.

55. Kumagai T, Muller Cl, Desmond JC, Imai Y, Heber D, Koeffler HP: Scutellaria baicalensis, a herbal medicine: anti-proliferative and apoptotic activity against acute lymphocytic leukemia, lymphoma and myeloma cell lines. Leuk Res 2007, 31(4):523-530.

56. Jung HS, Kim MH, Gwak NG, Im YS, Lee KY, Sohn Y, Choi H, Yang WM: Antiallergic effects of Scutellaria baicalensis on inflammation in vivo and in vitro. J Ethnopharmacol 2012, 141(1):345-349.

57. Kim WK, Kim JH, Jeong Da H, Chun YH, Kim SH, Cho KJ, Chang MJ: Radish (Raphanus sativus $L$. leaf) ethanol extract inhibits protein and mRNA expression of $\operatorname{ErbB}(2)$ and $\operatorname{ErbB}(3)$ in MDA-MB-231 human breast cancer cells. Nutr Res Pract 2011, 5(4):288-293.

58. Papi A, Orlandi M, Bartolini G, Barillari J, lori R, Paolini M, Ferroni F, Grazia Fumo M, Pedulli GF, Valgimigli L: Cytotoxic and antioxidant activity of 4-methylthio-3-butenyl isothiocyanate from Raphanus sativus L. (Kaiware Daikon) sprouts. J Agric Food Chem 2008, 56(3):875-883.

59. Yan Q, Li Y, Jiang Z, Sun Y, Zhu L, Ding Z: Antiproliferation and apoptosis of human tumor cell lines by a lectin (AMML) of Astragalus mongholicus. Phytomedicine 2009, 16(6-7):586-593.

60. Huang LH, Yan QJ, Kopparapu NK, Jiang ZQ, Sun Y: Astragalus membranaceus lectin (AML) induces caspase-dependent apoptosis in human leukemia cells. Cell Prolif 2012, 45(1):15-21.

61. Lam SK, Ng TB: First report of a haemagglutinin-induced apoptotic pathway in breast cancer cells. Biosci Rep 2010, 30(5):307-317.

62. Zhang M, Chiu LC, Cheung PC, Ooi VE: Growth-inhibitory effects of a betaglucan from the mycelium of Poria cocos on human breast carcinoma MCF-7 cells: cell-cycle arrest and apoptosis induction. Oncol Rep 2006, 15(3):637-643

63. Lee S, Ra J, Song JY, Gwak C, Kwon HJ, Yim SV, Hong SP, Kim J, Lee KH, Cho J, et al: Extracts from Citrus unshiu promote immune-mediated inhibition of tumor growth in a murine renal cell carcinoma model. J Ethnopharmacol 2011, 133(3):973-979.

64. Yadav VR, Prasad S, Sung B, Kannappan R, Aggarwal BB: Targeting inflammatory pathways by triterpenoids for prevention and treatment of cancer. Toxins (Basel) 2010, 2(10):2428-2466.

65. Yong $Y$, Shin SY, Lee $Y H$, Lim Y: Antitumor activity of deoxypodophyllotoxin isolated from Anthriscus sylvestris: Induction of G2/M cell cycle arrest and caspase-dependent apoptosis. Bioorg Med Chem Lett 2009, 19(15):4367-4371.

66. FDA: Guidance for industry: estimating the maximum safe starting dose in initial clinical trials for therapeutics in adult healthy volunteers. Rockville: Pharmacology and Toxicology; 2005.

67. Contoli M, Message SD, Laza-Stanca V, Edwards MR, Wark PA, Bartlett NW, Kebadze T, Mallia P, Stanciu LA, Parker HL, et al: Role of deficient type III interferon-lambda production in asthma exacerbations. Nat Med 2006, 12(9):1023-1026

68. Chung KF: Cytokines in chronic obstructive pulmonary disease. Eur Respir J Suppl 2001, 34:50s-59s.

69. Hackett TL, Stefanowicz D, Aminuddin F, Sin DD, Connett JE, Anthonisen $N R$, Pare PD, Sandford AJ: Effect of gene environment interactions on lung function and cardiovascular disease in COPD. Int J Chron Obstruct Pulmon Dis 2011, 6:277-287.

70. De Torres JP, Pinto-Plata V, Casanova C, Mullerova H, Cordoba-Lanus E, Muros De Fuentes M, Aguirre-Jaime A, Celli BR: C-reactive protein levels and survival in patients with moderate to very severe COPD. Chest 2008, 133(6):1336-1343.

71. Hurst JR, Donaldson GC, Perera WR, Wilkinson TM, Bilello JA, Hagan GW, Vessey RS, Wedzicha JA: Use of plasma biomarkers at exacerbation of chronic obstructive pulmonary disease. Am J Respir Crit Care Med 2006, 174(8):867-874.

72. Hurst JR, Perera WR, Wilkinson TM, Donaldson GC, Wedzicha JA: Systemic and upper and lower airway inflammation at exacerbation of chronic obstructive pulmonary disease. Am J Respir Crit Care Med 2006, 173(1):71-78
73. Wilkinson TM, Hurst JR, Perera WR, Wilks M, Donaldson GC, Wedzicha JA: Effect of interactions between lower airway bacterial and rhinoviral infection in exacerbations of COPD. Chest 2006, 129(2):317-324.

74. Yende S, Waterer GW, Tolley EA, Newman AB, Bauer DC, Taaffe DR, Jensen R, Crapo R, Rubin S, Nevitt M, et al: Inflammatory markers are associated with ventilatory limitation and muscle dysfunction in obstructive lung disease in well functioning elderly subjects. Thorax 2006, 61(1):10-16.

75. Kuhn C 3rd, Homer RJ, Zhu Z, Ward N, Flavell RA, Geba GP, Elias JA: Airway hyperresponsiveness and airway obstruction in transgenic mice. Morphologic correlates in mice overexpressing interleukin (IL)-11 and IL-6 in the lung. Am J Respir Cell Mol Biol 2000, 22(3):289-295.

doi:10.1186/1472-6882-13-176

Cite this article as: Sohn et al:: The effects of Gamijinhae-tang on elastase/lipopolysaccharide-induced lung inflammation in an animal model of acute lung injury. BMC Complementary and Alternative Medicine 2013 13:176.

\section{Submit your next manuscript to BioMed Central and take full advantage of:}

- Convenient online submission

- Thorough peer review

- No space constraints or color figure charges

- Immediate publication on acceptance

- Inclusion in PubMed, CAS, Scopus and Google Scholar

- Research which is freely available for redistribution 